\title{
A Cyclical Structure on Non-Performing Assets of Scheduled Commercial Banks in India
}

\author{
Prakash Chandrappa \\ Research Scholar, Department of Economics, Gulbarga University, Gulbarga, Karnataka.
}

\begin{abstract}
The Indian banking sector is facing a serious problem of NPA. The magnitude of NPA is comparatively higher in public sectors banks. To improve the efficiency and profitability of banks the NPA need to be reduced and controlled. NPAs have been fighting cyclical movement or dieses on week patient and it is an underdevelopment feature like chronic poverty. This paper deals with understanding the concept of NPAs, its magnitude and major causes for an account becoming non-performing and strategies for managing NPA in Indian banks. The best indicator for the health of the banking industry in a country is its level of Non-performing assets (NPAs). NPAs are one of the major concerns for banks in India. It reflects the performance of banks. Reduced NPAs generally gives the impression that banks have strengthened their credit appraisal processes over the years and growth in NPAs involves the necessity of provisions, which bring down the overalls profitability of banks.
\end{abstract}

Keywords: Indian Banking, PSBs, SCBs, cyclical, NPAs.

\section{Introduction}

It has been argued by a number of economists that a well-developed financial system enables smooth flow of savings and investments and hence, supports economic growth (see King and Levine, 1993, Goldsmith, 1969). A healthy financial system can help achieve efficient allocation of resources across time and space by reducing inefficiencies arising out of market frictions and other socio-economic factors. Amongst the various desirable characteristics of a well-functioning financial system, the maintenance of a few non-performing assets (NPA) is an important one. NPAs beyond a certain level are indeed cause for concern for everyone involved because credit is essential for economic growth and NPAs affect the smooth flow of credit. Banks raise resources not just on fresh deposits, but also by recycling the funds received from the borrowers. Thus, when a loan becomes non-performing, it affects recycling of credit and credit creation. Apart from this, NPAs affect profitability as well, since higher NPAs require higher provisioning, which means a large part of the profits needs to be kept aside as provision against bad loans. Therefore, the problem of NPAs is not the concern of the lenders alone but is, indeed, a concern for policy makers as well who are involved in putting economic growth on the fast track.

Non-Performing Assets NPAs remained a pressure point for the banking sector 4.19 The gross NPA ratio at the aggregate level stood at 3.6 per cent at end-March 2013 up from 3.1 per cent at end-March 2012 (Table IV.13). The deterioration in asset quality was most perceptible for the SBI Group with its NPA ratio reaching a high of 5 per cent at end-March 2013. With the gross NPA ratio reaching about 3.6 per cent by end-March 2013, the nationalized banks were positioned next to the SBI Group.

\section{Statement Of The Problem}

The NPAs of the Indian banking system have assumed large proportions and are a continuing deterrent to the smooth flow of credit to the productive sectors of industry and agriculture. The high level Committee on financial system (with Sh.M. Narasimham chairman) constituted by RBI (1991) to made recommendations on financial sector reforms also observed that serious problems are plaguing the financial sectors which is reflected in decline in productivity and efficiency and erosion of profitability due to deterioration in the quality of loan portfolio restricting income generation and enhancement of capital funds, accompanied by inadequate loan loss provisions. Concept of NPAs in its present forms came into existence with the recommendations of Narasimham Committee implemented by RBI in 1996. Level of NPAs as per these guidelines was first reflected in the bank's balance sheets of 1996-97.

\section{Review Of Literature}

Banerjee, (2006). Observed that non-performing assets are one of the problem areas which require attention for improvement in the management of PSBs and their profitability. The present scenario shows that the NPAs of PSBs are increasing very speedily. These NPAs cost the economy in several ways. First, the government has to bail out banks with budgetary provisions periodically and ultimately taxpayers bear the cost. Secondly, money borrowed for investment, if not utilized properly, affects the creation of assets and the growth of economy is endangered. The author has suggested several strategic measures to control NPAs of PSBs. 
Gupta, (2004). analyzed that redeeming features of banking sector reforms is the continuing fall in gross and net NPAs as a proportion of total assets for all bank groups except private sector banks. Huge backlog of NPAs needs resolution of the earthiest as otherwise it can weaken the foundation of entire financial system.

Jatna, (2009). reviewed that the root cause of increasing NPAs in public sector banks is malfunctioning of the banks. This malfunctioning led to the setting up of Narasimham Committee which, in fact, identified the NPA as one of the possible effects of the malfunctioning of PSBs. According to RBI report, 1999 it was stated that the reduction in NPA should be treated as a 'national priority'.

Krishnamurthi, (2000). States that the mounting NPAs are harmful for the public sector banks. It is seen that the gross NPAs of PSBs are rising very heavily. In banks the NPA curves vary between a gross of Rs.39,253 cores in 1992-'93 to Rs.45,653 cores in 1997-'98.

\section{Methodology}

The work is a mix of doctrinaire and empirical survey. It draws heavily from related books, articles, reports, case studies and internet. The data about Indian banking downloaded from internet is crosschecked by the relevant RBI reports.

\section{Scope OF Npas}

A Non-Performing Asset (NPA) is an advance where.

Interest and/or instalment of principal remains overdue for a period of more than 180 days in respect of a term loan, $(\mathrm{OD} / \mathrm{CC})$,

The account remains out of order for a period of more than 180 days in respect of an overdraft/cash credit discounted,

The bill remains overdue for a period of more than 180 days in the case of bills purchased and Interest and/or instalment of principal remains overdue for two harvest seasons or for a period not exceeding two half years in the case of an advance granted for agricultural purposes.

Any amount to be received remains overdue for a period of more than 180 days in respect of any other accounts.

The mid-term review of the Monetary and Credit Policy of the Reserve Bank of India for the year 2002-03 announced a 90-day-norm for the recognition for loan impairment which has been extended to the StCBs/DCCBs from the year ending 31.03.2006. With effect from March 31, 2006, NPAs include amounts. Interest and/or instalment of principal remaining overdue for a period of more than 90 days in respect of a term loan. (OD/CC).

The amount remains out of order for a period of more than 90 days in respect of a Overdraft/Cash Credit

The bill remains overdue for a period of more than 90 days in the case of bills purchased and discounted.

In respect of direct agricultural loans the existing norms of classification of NPA will continue. (All direct agricultural advances will be classified as NPA of the interest and/or instalments of principal remains overdue for two harvest seasons but for a period not exceeding two half years). But, in respect of other agricultural loans for allied agricultural activities, 90 days norms will apply.

Any amount to be received remains overdue for a period of more than 90 days in respect of all other accounts.

Rs in Billion

\section{Gross And Net Npas Of Scheduled Commercial Banks}

\begin{tabular}{|c|c|c|c|c|c|c|c|c|}
\hline \multicolumn{9}{|c|}{ Non-Performing Assets } \\
\hline & \multirow[t]{2}{*}{ Gross } & \multirow[t]{2}{*}{ Net } & \multicolumn{3}{|c|}{ Gross } & \multicolumn{3}{|c|}{ Net } \\
\hline & & & Amount & $\% \mathbf{G A}$ & $\% \mathbf{T A}$ & Amount & $\% \mathrm{NA}$ & $\% \mathbf{T A}$ \\
\hline (1) & (2) & (3) & (4) & (5) & $(6)$ & (7) & (8) & (9) \\
\hline 2005-06 & 15513.78 & 15168.11 & 510.97 & 3.3 & 1.8 & 185.43 & 1.2 & 0.7 \\
\hline 2006-07 & 20125.10 & 19812.37 & $\mathbf{5 0 4 . 8 6}$ & 2.5 & 1.5 & 201.01 & 1.0 & 0.6 \\
\hline 2007-08 & 25078.85 & 24769.36 & 563.09 & 2.3 & 1.3 & 247.30 & 1.0 & 0.6 \\
\hline 2008-09 & 30382.54 & 29999.24 & 683.28 & 2.3 & 1.3 & 315.64 & 1.1 & 0.6 \\
\hline 2009-10 & 35449.65 & 34970.92 & 846.98 & 2.4 & 1.4 & 387.23 & 1.1 & 0.6 \\
\hline 2010-11 & 40120.79 & 42987.04 & 979.22 & 2.4 & 1.4 & 418.13 & 1.0 & 0.6 \\
\hline 2011-12 & 46655.44 & 50746.00 & 1423.00 & 3.1 & 1.7 & 649.00 & 1.4 & 0.8 \\
\hline
\end{tabular}

Source: Off-site returns (domestic and provisional) of Banks, Department of Banking Supervision, RBI. (\%-percent, GA-gross asset, TA-total asset, NA-net asset) 


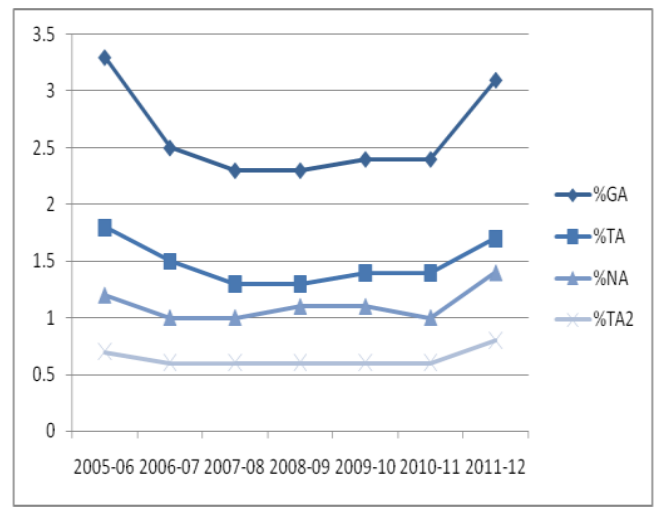

\section{Data And Interpitation}

Above the table and diagram exploring gross and net non-performing assets of scheduled commercial banks. In the year of 2005-06 total asset is 1.8 per cent in gross asset 3.3 and net asset is $1.2 \%$ includes net total asset is $0.7 \%$. In the year of 2006-07 the gross asset is declined $2.5 \%$ as compared early year and gross total asset in declined 1.5. In the year 2011-12 the gross asset takes a place of upward by 2010-11 it was $2.4 \%$ now it 3.1\% the gross total asset was $1.4 \%$ in the year of 2010-11 while we take year of 2011-12 it is $1.7 \%$. The net asset is $1.4 \%$ and net total asset is $0.8 \%$ of 2011-12 early year net assets $1.0 \%$ and net total asset was $0.6 \%$. The table and scatter diagram give an evidence of cyclical movement on non-performing assets by year to year.

\section{Findings And Discussions}

Non-Performing Assets is a chronic melody of banking sector as a results of this study got an idea regarding NPAs. It had been cyclical situation while banks are providing loan and advances to client. Huge backlog of NPAs needs resolution of the earthiest as otherwise it can weaken the foundation of entire financial system. To create more conducive recovery climate among the borrowers and profitability of banks through better recoveries, the RBI and the Central Government have initiated several institutional measures, which include Debt Recovery Tribunals (DRTs), Lok Adalats, Asset Reconstruction Companies (ARCs), Corporate Debt Restructuring (CDR) Mechanism, Settlement Advisory Committees (SACs) have also been formed at the regional and head office levels of commercial banks. Furthermore, the banks can also issue notices under SARFARESI Act, 2002 for enforcement of security interest without intervention of the courts.

\section{References}

[1]. Banerjee. (2006), "Management of Non-performing Advances in the Public Sector Banks in India", New Trends in Corporate Reporting (Edited Book), RBSA Publishers, Jaipur, pp. 115-137

[2]. Cheema. (2012), "SARFAESI Act: Delaying Tactics Used by the Borrowers”, Bank Quest, Vol. 83, no. 1, Jan.-March, 2012, pp. 43-51.

[3]. Desai. (2010), Bank Management, Himalaya Publishing House Pvt. Ltd., New Delhi

[4]. Gupta. (2004), "Dimensions and Prospectus of Non-performing Assets: Challenges Before the Banking Sector Reforms in the New Millennium", Edited Book Banking in the New Millennium, pp. 279-291.

[5]. Jatna. (2009), "Impact of NPAs on Profitability of Banks", Indian Journal of Accounting, Vol. XXXIX, no. 2, June, 2009, pp. 21-27 Kothari. (2006), Research Methodology: Methods and Techniques, New Age International Publishers, New Delhi

[6]. Krishnamurthi. (2000), "Non-performing Assets- Banks and Financial Institutions: NPAs Plaguing National Economy", Southern Economist, Vol. 38, no. 5, July, 2000, pp. 19-20 